\title{
A RARE CASE OF BROWN TUMOUR OVER LEFT ILIUM- A CASE REPORT
}

\author{
P. V. Pugalenthi', V. R. Ganesan², K. Kailash ${ }^{3}$
}

1 Professor and HOD, Department of Orthopaedics and Traumatology, Government Rajaji Hospital, Madurai, Tamilnadu.

2Professor, Department of Orthopaedics and Traumatology, Government Rajaji Hospital, Madurai, Tamilnadu.

3Postgraduate Student, Department of Orthopaedics and Traumatology, Government Rajaji Hospital, Madurai, Tamilnadu.

HOW TO CITE THIS ARTICLE: Pugalenthi PV, Ganesan VR, Kailash K. A rare case of brown tumour over left ilium- a case report. J. Evolution Med. Dent. Sci. 2018;7(20):2517-2518, DOI: 10.14260/jemds/2018/565

\section{PRESENTATION OF CASE}

A 40 years old female patient came to our hospital with pain over left iliac bone, which was gradually increased since 8 months and was unable to bear weight on left lower limb for last 2 weeks. On physical examination, tenderness was determined over the left iliac region. On neck examination, the right inferior thyroid lobe, $4 \times 3 \mathrm{~cm}$ sized, palpable nodule and soft in consistency was noticed. Other systemic examinations revealed no abnormality. Laboratory analysis revealed serum calcium- $13.9 \mathrm{mg} / \mathrm{dL}$, serum alkaline phosphatase- $812 \mathrm{IU} / \mathrm{L}$ and serum parathyroid hormone level was $2056 \mathrm{pg} / \mathrm{mL}$ and other blood investigations were found to be normal. All these findings are more in favour for hyperparathyroidism due to parathyroid adenoma.

On Roentgenography an expansile, osteolytic lesion, eccentrically situated with sharp sclerosed margin involving the left iliac bone; on MRI Heterogeneous mixed signal intensity lesion replacing the normal visualised pelvic bone with right iliac bone measuring $4.5 * 4.1 \mathrm{~cm}$ and left iliac bone measuring $5.2 * 4.1 \mathrm{~cm}$ and left iliac crust lesion measuring $1.82 \mathrm{~cm}$ approximately.

Brown tumour is a type of lesion associated with hypersecretion of parathormone. It is a benign condition. It is the terminal stage of the remodelling process in hyperparathyroid state. It is a rare clinical presentation of primary hyperparathyroidism which is probably due to adenoma, secreting parathormone (PTH). Increased PTH levels cause resorption of bone leading to polyostotic lesions. There will be reduction in bone mineral density (BMD) causing osteolytic lesions. Here, we report a case of 40 years old female who presented with pain over left iliac region. On examination, tenderness was present over left iliac region. Radiological and blood investigations were done. She was found to have osteolytic lesions over right and left iliac wing with hyperparathyroidism and on further investigations parathyroid adenoma was noted. She was treated with surgical excision of parathyroid after confirmation with the biopsy report and histopathological, biochemical investigations. At the follow-up time, patient was free of symptoms. Brown tumour is a benign lesion associated with hyperparathyroidism. Any patient with osteolytic lesion with neck swelling should be undergoing serum PTH level with whole skeletal screening, as multiple cystic lesions may present in brown tumour patient.

'Financial or Other Competing Interest': None.

Submission 28-02-2018, Peer Review 27-04-2018,

Acceptance 02-05-2018, Published 14-05-2018.

Corresponding Author:

Dr. K. Kailash,

Room No. 206, OASIS PG Hostel,

Madurai-625022

E-mail: kailashkathiresani10@gmail.com

DOI: $10.14260 /$ jemds/2018/565

(c) $($ i) $(9)$
Parathyroidectomy is the treatment with other orthopaedic interventions. Primary hyperparathyroidism is due to parathyroid adenoma that causes oversecretion of parathormone (PTH). The effects of hypercalcaemia is related with the size of parathyroid adenoma. ${ }^{1}$ Solitary parathyroid adenoma is the single cause of hypersecretion of parathormone (single gland disease), whereas very few patients have hyperplasia (multiple gland disease) and $1 \%$ have carcinoma. Hypersecretion of parathormone causes excess calcium reabsorption from kidneys and increased excretion of phosphates in urine and increased vitamin $\mathrm{D}$ production. It increases the activity of osteoclasts, predisposes the bone to pathologic fracture due to reduction in bone mineral density. ${ }^{2}$ In this case report, we have discussed a rare presentation of the patient having parathyroid adenoma with cystic lesion in left iliac bone.

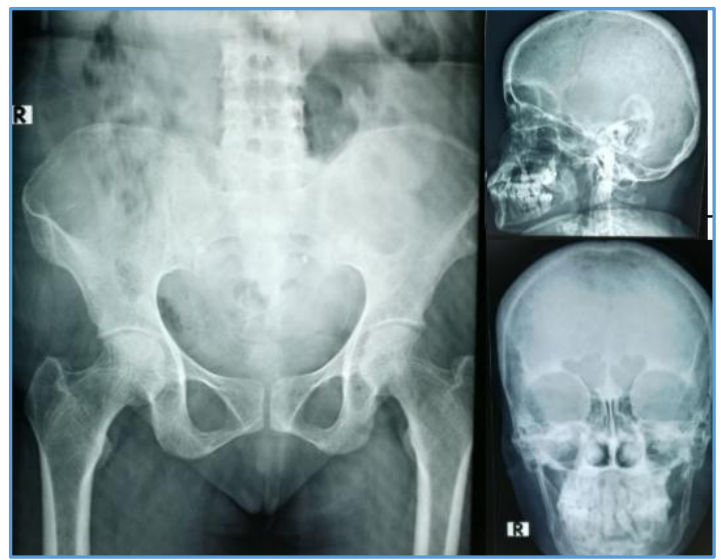

Osteolytic Lesions seen over both Right and Left Ilium

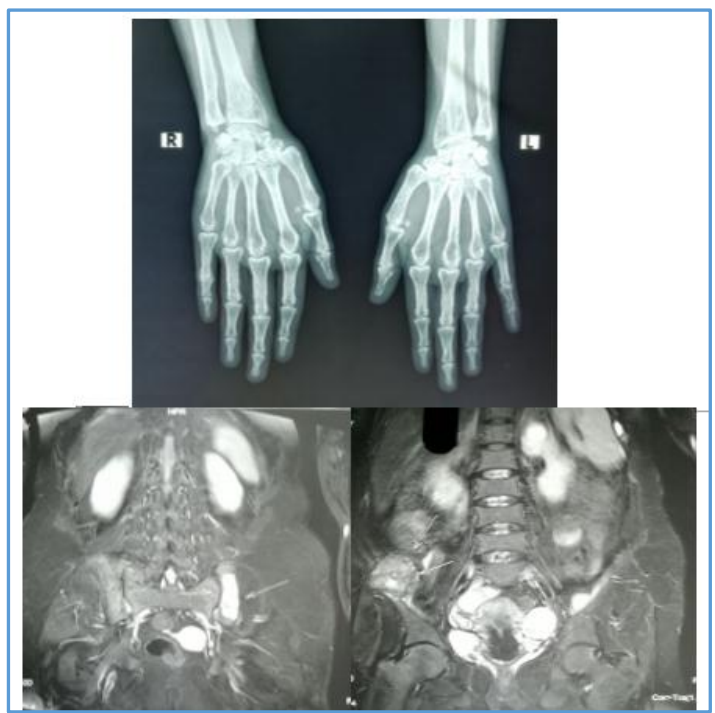

On USG of Neck ${ }^{3}$ Mass was seen, Hypoechoic Homogeneous Nodule Localised over Thyroid Gland Region 


\section{CLINICAL DIAGNOSIS}

Elevated serum calcium, serum alkaline phosphatase with tenderness over left ilium and lytic lesion in ilium with swelling in thyroid region goes in favour of parathyroid adenoma.

\section{DISCUSSION}

The prevalence rate of primary hyperparathyroidism ranges from $1 \%$ to $5 \%$. Females are affected more in the ratio of female: male ratio of $3: 1$. In majority of cases, the cause is a solitary adenoma and a few report to have a glandular hyperplasia. Serum calcium, ionised calcium and PTH levels must be obtained for diagnosing hyperparathyroidism. Brown tumours are not common lesions associated with hyperparathyroidism due to abnormal osteoclastic and osteoblastic activity causing bone resorption. The incidence of brown tumours is $1.5 \%$. Nowadays, brown tumour have become extremely rare due to early diagnosis and medical management of hyperparathyroidism. Radiological investigations have showed multiple localised lytic lesions. It affects mainly cortical bone and cancellous bone are spared. The bone marrow in cysts are replaced by vascularised fibrous tissue. These tumours often manifest as benign, painful masses with tendency to pathological fracture. Histologically, these tumours are characterised by numerous giant cells and these cells are diffuse or arranged in clusters. Brown tumours resemble giant cell tumours of bone and it must be correlated with clinical and radiographical data for correct diagnosis. Organisation of haemorrhagic lesions results in the release of hemosiderin and the accumulation of macrophages, fibroblasts and giant cells. In our case, patient has multiple cystic lesions in the skeleton. Similar radiologic features are seen in other cystic bony lesions. The multiplicity of these lesions in combination with increased serum level of PTH confirms our diagnosis. Sestamibi scan, 4 however, is indicated for ectopic PTH producing adenoma. Surgical exploration of the neck is recommended in hyperparathyroid bone disease and hypercalcaemia. The serum PTH level falls dramatically after parathyroidectomy ${ }^{5,6}$ causing reduction in bone resorption and there will be marked increase in bone uptake of calcium and phosphate. ${ }^{7}$ Hence, patient presenting with pathological fracture, one of the differential diagnosis must be primary hyperparathyroidism. Fracture fixation with parathyroidectomy will provide complete treatment.

\section{FINAL DIAGNOSIS}

Macroscopic examination of the excised gland revealed greyish-brown soft tissue mass measuring $5 \times 4 \times 2 \mathrm{cms}$ and on cut section cystic area.

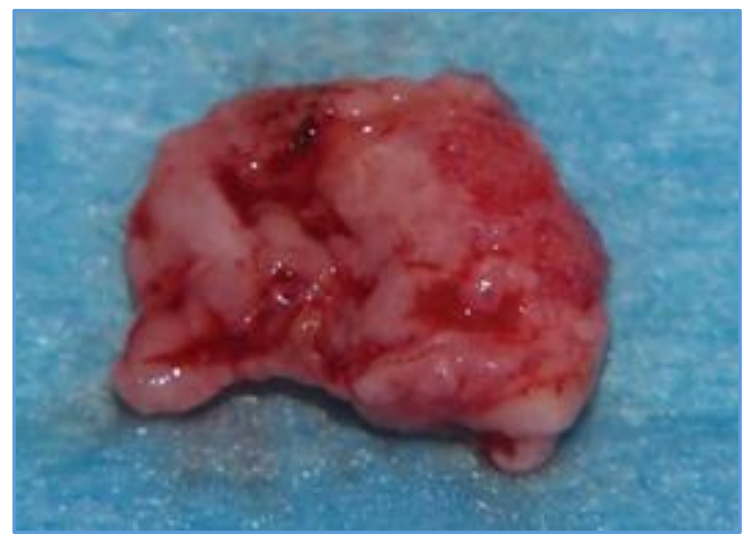

Surgical Excision of the Parathyroid Gland

Microscopic examination showed the presence of oxyphilic cells and chief cells arranged in follicular and pseudopapillary patterns, separated by sinusoidal cells. Individual cells showed mild degree of pleomorphism, hyperchromatism and crowding of nucleus suggesting of parathyroid adenoma.

Post-operatively, patient's serum level of calcium was 9.6 $\mathrm{mg} / \mathrm{dL}$ and serum level of parathyroid was $244 \mathrm{pg} / \mathrm{mL}$. Patient was given oral calcium and vitamin D and advised non-weightbearing for 8 weeks. And patient was now able to bear weight on left leg with full range of movements and there were no other complications till the last follow-up.

\section{REFERENCES}

[1] Rubin E, Farber JL. Pathology. $3^{\text {rd }}$ edn. Philadelphia: Lippincott Williams \& Wilkins 1999: p. 569.

[2] Heath DA. Primary hyperparathyroidism. Clinical presentation and factors influencing clinical management. Endocrinol Metab Clin North Am 1989;18(3):631-46.

[3] Scheible W, Deutsch AL, Leopold GR. Parathyroid adenoma: accuracy of preoperative localization by high resolution real-time sonography. J Clin Ultrasound 1981;9(6):325-30.

[4] Krubsack AJ, Wilson SD, Lawson TL, et al. Prospective comparison of radionuclide, computed tomographic and sonographic localization of parathyroid tumors. World J Surg 1986;10(4):579-85.

[5] Delbridge LW, Younes NA, Guinea AI, et al. Surgery for primary hyperparathyroidism 1962-1996: indications and outcomes. Med J Aust 1998;168(4):153-6.

[6] Chen H, Parkerson S, Udelsman R. Parathyroidectomy in the elderly: do the benefits outweigh the risks? World J Surg 1998;22(6):531-5, discussion 535-6.

[7] Singhal S, Johnson CA, Udelsman R. Primary hyperparathyroidism: what every orthopedic surgeon should know. Orthopedics 2001;24(10):1003-9, quiz 1010-1. 